\title{
Growth and antimicrobial activity of lactic acid bacteria from rumen fluid according to energy or nitrogen source ${ }^{1}$
}

\author{
Isabela Pena Carvalho de Carvalho², Edenio Detmann ${ }^{3}$, Hilário Cuquetto Mantovani ${ }^{4}$, Mário \\ Fonseca Paulino ${ }^{3}$, Sebastião de Campos Valadares Filho ${ }^{3}$, Viviane Aparecida Carli Costa ${ }^{5}$, \\ Daiany Iris Gomes ${ }^{6}$
}

\footnotetext{
1 Financial support: FAPEMIG, CNPq and INCT - Ciência Animal.

2 Programa de Pós-Graduação em Zootecnia, Universidade Estadual Paulista, Jaboticabal-SP.

${ }^{3}$ Departamento de Zootecnia, Universidade Federal de Viçosa, Viçosa-MG. Pesquisador do CNPq e do INCT-Ciência Animal.

${ }^{4}$ Departamento de Microbiologia, Universidade Federal de Viçosa, Viçosa-MG. Pesquisador do CNPq.

5 LZNA, Universidade Estadual do Norte Fluminense, Campos dos Goytacazes-RJ.

${ }^{6}$ Programa de Pós-Graduação em Zootecnia, Universidade Federal de Viçosa, Viçosa-MG.
}

ABSTRACT - The objective of this study was to evaluate the effects of supplementation with different sources of energy and nitrogenous compounds on the in vitro growth and production of bacteriocin of lactic acid bacteria. Incubations were performed by using ruminal fluid from a rumen-fistulated Holstein-Zebu steer. The animal was kept on a Brachiaria decumbens pasture receiving $200 \mathrm{~g} /$ day of supplemental crude protein. Substrates and inoculum were placed in glass flasks considering eight treatments: cellulose, cellulose and casein, cellulose and soy peptone, cellulose and urea, starch, starch and casein, starch and soy peptone and starch and urea. Successive incubations were conducted to select microorganisms according to the energy sources and nitrogenous compounds. Starch favoured growth of lactic acid bacteria when compared to cellulose. Supplementation with true protein (soy peptone and casein) stimulated the growth of these bacteria when compared to the control (without supplementation with nitrogenous compounds). The addition of urea did not stimulate the growth of lactic acid bacteria. No antimicrobial activity was detected from colonies of isolated lactic acid bacteria. Sources of true protein increase the competition between non-structural and structural carbohydrates fermenting bacteria.

Key Words: bacteriocin, cellulose, protein effect, rumen microbiology

\section{Crescimento e atividade antimicrobiana de bactérias ácido-láticas do líquido ruminal de acordo com a fonte de energia ou de compostos nitrogenados}

\begin{abstract}
RESUMO - Objetivou-se avaliar os efeitos da suplementação com diferentes fontes de energia e de compostos nitrogenados sobre o crescimento e produção de bacteriocinas de bactérias ácido-láticas in vitro. As incubações foram conduzidas utilizando-se fluido ruminal originado de um novilho Holandês-Zebu fistulado no rúmen. O animal foi mantido em pastagem de Brachiaria decumbens recebendo $200 \mathrm{~g} /$ dia de proteína bruta suplementar. Os substratos e o inóculo foram acondicionados em frascos de vidro considerando-se oito tratamentos: celulose, celulose e caseína, celulose e peptona de soja, celulose e ureia, amido, amido e caseína, amido e peptona de soja e amido e ureia. Incubações sucessivas foram conduzidas para seleção dos microrganismos em função das fontes energéticas e de compostos nitrogenados. $\mathrm{O}$ amido favoreceu o crescimento de bactérias ácido-láticas em comparação à celulose. A suplementação com proteína verdadeira (peptona de soja e caseína) estimulou o crescimento dessas bactérias em comparação ao controle (sem suplementação com compostos nitrogenados). A adição de ureia não estimulou o crescimento de bactérias ácido-láticas. Nenhuma atividade antimicrobiana foi detectada a partir das colônias de bactérias ácido-láticas isoladas. Fontes de proteína verdadeira incrementam a competição entre bactérias fermentadoras de carboidratos estruturais e não-estruturais.
\end{abstract}

Palavras-chave: bacteriocinas, celulose, efeito proteína, microbiologia do rúmen

\section{Introduction}

Recent studies conducted under tropical conditions showed increases in animal production when supplemental sources of non-protein nitrogen were added to the diet (Paulino et al., 2005; Porto, 2005; Paulino et al., 2008; Costa, 2009).

On the other hand, despite the beneficial effects of nitrogen on ruminal fibrolytic activity when low-quality 
forage is offered to animals (Detmann et al., 2009), several in vitro studies concluded that supplementation with true protein causes deleterious effects on the degradation of neutral detergent fiber (NDF) from high-quality forage (Paez-Bernal, 2007; Costa et al., 2009; Zorzi et al., 2009), and reductions in gas production from carbohydrates (Cone \& Van Gelder, 1999; Mould et al., 2005; Oliveira et al., 2005). However, these negative effects would not be observed upon the addition of urea to the medium (Paez-Bernal, 2007; Zorzi et al., 2009).

The negative effect of true protein supplementation was called "protein effect" (Costa et al., 2009). Microbial interactions, such as competition or a change in the prioritisation of substrate usage, could also explain the occurrence of "protein effect" on the degradation of NDF from high quality tropical forages (Paez-Bernal, 2007; Costa et al., 2009).

In some studies conducted under tropical conditions, it has been speculated that negative effects of the addition of protein should be attributed to the occurrence of antagonistic interactions between microbial species, such as growth inhibition mediated by bacteriocins (Paez-Bernal, 2007; Costa et al., 2009; Zorzi et al., 2009). The production of these inhibitory compounds may be enhanced by increasing the supply of amino acids, which favours the growth of bacteriocin-producing microbial species (De Vuyst \& Vandamme, 1993; Kim et al., 1997; Parente \& Ricciardi, 1999; Aasen et al., 2000). Bacteriocins may reduce the cellulolytic activity in the rumen (Wolin et al., 1997).

The objective of this study was to evaluate the effects of supplementation with different nitrogen sources on the growth and production of bacteriocins of lactic acid bacteria (LAB) from rumen in vitro.

\section{Material and Methods}

The experiment was conducted in the Laboratório de Nutrição Animal and Laboratório de Microbiologia Anaerobica at the Universidade Federal de Viçosa.
The rumen content used as inoculum for in vitro incubations was obtained from a crossbred rumen-fistulated Holstein-Zebu steer (350 kg of body weight). This steer was fed a diet composed of signal grass (Brachiaria decumbens) pasture during the rainy season (from December 2007 to February 2008) and $200 \mathrm{~g}$ /day of supplemental crude protein (CP). Two-thirds of the $\mathrm{CP}$ was in the form of albumin (source of true protein) and 1/3 was in the form of urea (source of non-protein nitrogen). Supplement was provided daily via rumen infusion at 12 p.m.

The liquid portion of the rumen content was collected through the fistula at 11 a.m. (after morning grazing, but before supplement infusion), filtered through three layers of cheesecloth and maintained anaerobically in an Erlenmeyer flask for $30 \mathrm{~min}$ at $39^{\circ} \mathrm{C}$ to separate liquid and particulate phases.

Samples from the liquid phase were anaerobically transferred to test tubes and centrifuged ( $3000 \mathrm{x} \mathrm{g} / 5 \mathrm{~min})$. The supernatant was discarded and the cell pellet was resuspended in basal medium containing, per litre, $4 \mathrm{~g}$ of glucose, $292 \mathrm{mg}$ of $\mathrm{K}_{2} \mathrm{HPO}_{4}, 480 \mathrm{mg}$ of $\left(\mathrm{NH}_{4}\right)_{2} \mathrm{SO}_{4}, 480 \mathrm{mg}$ of $\mathrm{NaCl}, 100 \mathrm{mg}$ of $\mathrm{MgSO}_{4} \cdot 7 \mathrm{H}_{2} \mathrm{O}, 64 \mathrm{mg}$ of $\mathrm{CaCl}_{2} \cdot 2 \mathrm{H}_{2} \mathrm{O}$, $500 \mathrm{mg}$ of cysteine, $1 \mathrm{~g}$ of trypticase, $4 \mathrm{~g}$ of $\mathrm{Na}_{2} \mathrm{CO}_{3}, 0.5 \mathrm{~g}$ of yeast extract, $177 \mu \mathrm{L}$ of acetic acid, $63 \mu \mathrm{L}$ of propionic acid, $31 \mu \mathrm{L}$ of butyric acid, $11 \mu \mathrm{L}$ of valeric acid, $11 \mu \mathrm{L}$ of isovaleric acid and $11 \mu \mathrm{L}$ of isobutyric acid. After standardisation of the optical density $\left(\mathrm{DO}_{600 \mathrm{~nm}}\right)$ to 2.00 , the cellular suspension was used as inocula for in vitro incubations.

Glass flasks $(50 \mathrm{~mL})$ containing microcrystalline cellulose $\left(\right.$ Avicel $\left.^{\circledR}\right)(350 \mathrm{mg}$ ) or starch (Merck 101252) (350 mg) were added with different nitrogen sources to a final concentration of $4 \mathrm{mg} \mathrm{CP} / \mathrm{mL}$. The following treatments were evaluated : cellulose, cellulose and casein, cellulose and soy peptone, cellulose and urea, starch, starch and casein, starch and soy peptone, and starch and urea (Table1).

Sigma $^{\circledR}$ C7078 casein, Isofar $^{\circledR} 744$ urea, Merck ${ }^{\circledR}$ A596117611 ammonium sulphate, and Biobrás ${ }^{\circledR}$ soy peptone were used as nitrogen sources in this study. In treatments

Table 1 - Description of the compounds added to in vitro system according to the treatments

\begin{tabular}{|c|c|c|c|c|c|c|c|c|}
\hline \multirow[b]{2}{*}{ Compound } & \multicolumn{8}{|c|}{ Treatment } \\
\hline & Cellulose & $\begin{array}{l}\text { Cellulose } \\
\text { and casein }\end{array}$ & $\begin{array}{l}\text { Cellulose and } \\
\text { soy peptone }\end{array}$ & $\begin{array}{l}\text { Cellulose } \\
\text { and urea }\end{array}$ & Starch & $\begin{array}{c}\text { Starch } \\
\text { and casein }\end{array}$ & $\begin{array}{l}\text { Starch and } \\
\text { soy peptone }\end{array}$ & $\begin{array}{l}\text { Starch } \\
\text { and urea }\end{array}$ \\
\hline Cellulose (mg) & 350 & 350 & 350 & 350 & & & & \\
\hline Starch (mg) & & & & & 350 & 350 & 350 & 350 \\
\hline Casein (mg) & & 176.8 & & & & 176.8 & & \\
\hline Soy peptone (mg) & & & 211.1 & & & & 211.1 & \\
\hline $\mathrm{U}: \mathrm{AS}(\mathrm{mg})^{1}$ & & & & 54.6 & & & & 54.6 \\
\hline Inoculum (mL) & 7 & 7 & 7 & 7 & 7 & 7 & 7 & 7 \\
\hline Basal medium $(\mathrm{mL})$ & 28 & 28 & 28 & 28 & 28 & 28 & 28 & 28 \\
\hline
\end{tabular}

${ }^{1}$ Urea:ammonim sulphate at 9:1 ratio. 
involving urea supplementation, an urea:ammonium sulphate mixture was used at 9:1 ratio. The inclusion of ammonium sulphate was done to provide sulphur as precursor for sulphurous amino acids synthesis.

Basal medium $(28 \mathrm{~mL})$ was added to the flasks under constant $\mathrm{CO}_{2}$ flow to maintain an anaerobic environment. Seven millilitres of the inoculum were added and the flasks were sealed immediately and incubated at $39^{\circ} \mathrm{C}$ under orbital agitation $(70 \mathrm{rpm})$. Fermentation gases were removed from the batch cultures every three hours.

After 24 hours of incubation, the flasks were opened under an atmosphere of $\mathrm{CO}_{2}$ and the content $(7 \mathrm{~mL})$ was used to inoculate a second batch culture. The treatments of the first incubation were maintained. This procedure was performed successively until the fourth transfer to select for microorganisms utilizing a particular source of energy and nitrogen.

MRS media was used for the selective plating of LAB (De Man et al., 1960; pH 5.4). The culture medium was prepared anaerobically and transferred into flasks sealed with rubber stoppers and aluminium seals. Subsequently, the medium was poured into polyethylene petri plates $(90 \times 15 \mathrm{~mm})$ in an anaerobic chamber (COY Laboratory Products Inc., Grass Lake, MI, USA) under an atmosphere of $\mathrm{CO}_{2}$ and $\mathrm{H}_{2}(95: 5)$ at $39^{\circ} \mathrm{C}$.

The inoculum resulting from the third and fourth transfers was successively diluted in sodium phosphate buffer ( $5 \mathrm{mM}, \mathrm{pH} 6.5$ ), with dilutions ranging from $10^{-1}$ to $10^{-8}$. Next, $100 \mu \mathrm{L}$ of each dilution was spread on the surface of MRS medium ( $\mathrm{pH}$ 5.4). The batch cultures were removed from the anaerobic chamber and the $\mathrm{pH}$ was verified by a digital potentiometer. After 48 hours of incubation, the plates were removed from the anaerobic chamber and colonyforming units per $\mathrm{mL}$ were determined $(\mathrm{CFU} / \mathrm{mL})$.

To detect the presence of antimicrobial substances that could inhibit microbial growth, the occurrence of inhibitory activity among LAB obtained in the previous procedure was evaluated.

LAB colonies that grew on the plates used for enumeration were transferred to microcentrifuge tubes containing $1 \mathrm{~mL}$ of fresh MRS medium ( $\mathrm{pH} \mathrm{5.4)} \mathrm{and}$ incubated at $39^{\circ} \mathrm{C}$ for 24 hours. Micro drops of these LAB cultures $(5 \mu \mathrm{L})$ were spread onto plates containing solid MRS medium (pH 5.4) and incubated for 24 hours at $39^{\circ} \mathrm{C}$. After 24 hours, the LAB colonies were overlayed with the indicator organism and the plates were incubated for 12 hours at $4^{\circ} \mathrm{C}$ to allow diffusion to occur.

Lactococcus lactis and Ruminococcus albus were used as indicator organisms. L. lactis was cultivated in MRS medium (pH 6.8) and R. albus was cultivated in "Caldwell and Bryant" modified PPB medium (Atlas, 2005). The medium contained, per litre, $4 \mathrm{~g}$ of glucose, $2 \mathrm{~g}$ of trypticase, $2 \mathrm{~g}$ of yeast extract, $150 \mathrm{~mL}$ of clarified rumen fluid, $292 \mathrm{mg}$ of $\mathrm{K}_{2} \mathrm{HPO}_{4}, 480 \mathrm{mg}$ of $\left(\mathrm{NH}_{4}\right)_{2} \mathrm{SO}_{4}, 480 \mathrm{mg}$ of $\mathrm{NaCl}, 100 \mathrm{mg}$ of $\mathrm{MgSO}_{4} \cdot 7 \mathrm{H}_{2} \mathrm{O}, 64 \mathrm{mg}$ of $\mathrm{CaCl}_{2} \cdot 2 \mathrm{H}_{2} \mathrm{O}, 4 \mathrm{~g}$ of $\mathrm{Na}_{2} \mathrm{CO}_{3}, 25 \mathrm{mg}$ of cysteine, $5 \mathrm{mg}$ of hemin, $177 \mu \mathrm{L}$ of acetic acid, $63 \mu \mathrm{L}$ of propionic acid, $31 \mu \mathrm{L}$ of butyric acid, $11 \mu \mathrm{L}$ of valeric acid, $11 \mu \mathrm{L}$ of isovaleric acid and $11 \mu \mathrm{L}$ of isobutyric acid.

After the diffusion period, the plates were incubated for 24 to 48 hours at $37^{\circ} \mathrm{C}$ and $39^{\circ} \mathrm{C}$ for L. lactis and R. albus, respectively.

To evaluate the antimicrobial activity in the supernatants of the isolated cultures, it was used the agar diffusion method described by Tagg et al. (1976). Samples of the supernatant from each culture $(25 \mu \mathrm{L})$ were applied to $5-\mathrm{mm}$ diameter agar wells. The media contained $10^{6} \mathrm{CFU} / \mathrm{mL}$ of the indicator microorganism (L. lactis).

Incubation procedures were repeated four times. The data were evaluated for normality and homoscedasticity, according to the tests of Lilliefors and Bartlett, respectively $(\alpha=0.05)$. However, the LAB enumeration was not found to follow these basic assumptions $(\mathrm{P}<0.05)$ and it was transformed based on a decimal logarithm scale. After the transformation, the conditions of normality and homoscedasticity were verified $(\mathrm{P}>0.05)$.

The data were subjected to analysis of variance according to a randomized block design, where the incubations were considered blocks, and analysed in a $2 \times 4$ factorial arrangement (two sources of energy and four sources of nitrogenous compounds), according to the model:

$$
Y_{i j k}=\mu+E_{i}+N_{j}+E N_{i j}+B_{k}+\varepsilon_{i j k}
$$

where $\mu=$ the general constant, $\mathrm{E}_{\mathrm{i}}=$ the effect of energy source $i$ (fixed), $N_{j}=$ the effect of nitrogenous compounds source $\mathrm{j}$ (fixed), $\mathrm{EN}_{\mathrm{ij}}=$ the interaction of energy source $\mathrm{i}$ and nitrogenous compounds source $\mathrm{j}$ (fixed), $\mathrm{B}_{\mathrm{k}}=$ the effect of block or incubation replicate $\mathrm{j}$ (random), and $\varepsilon_{\mathrm{ijk}}=$ the random error supposed to be normally and independently distributed with average 0 and variance $\sigma^{2}$.

When necessary, means were compared by using Tukey test. All statistical procedures were conducted assuming $\alpha=0.05$.

\section{Results and Discussion}

There was no interaction effect between energy and nitrogen sources $(\mathrm{P}>0.05)$.

After three transfers, LAB growth was favoured $(\mathrm{P}<0.05)$ when starch was used as energy source in comparison to cellulose (Table 2). Sources of protein (soy peptone and 
casein) stimulated the growth of LAB $(\mathrm{P}<0.05)$ when compared to urea (Table 2).

The $\mathrm{pH}$ was not affected by the energy source $(\mathrm{P}>0.05)$; however, the inclusion of urea resulted in increased $\mathrm{pH}(\mathrm{P}<0.05)$ when compared to other sources of nitrogen (Table 2).

After the fourth transfer, LAB growth was favoured $(\mathrm{P}<0.05)$ when starch was used as an energy source (Table 3 ).
As in the third transfer, the protein sources stimulated the growth of LAB $(\mathrm{P}<0.05)$ whereas urea provided a LAB concentration similar to the control $(\mathrm{P}>0.05)$ (Table 3$)$.

The $\mathrm{pH}$ was not affected by the energy source $(\mathrm{P}>0.05)$ after the fourth transfer; however, the inclusion of urea resulted in a higher $\mathrm{pH}(\mathrm{P}<0.05)$ when compared to the other sources of nitrogen (Table 3 ).

Table 2 - Concentration of lactic acid bacteria and $\mathrm{pH}$ of the culture after the third rumen inoculum transfer

\begin{tabular}{|c|c|c|c|c|c|}
\hline \multirow[b]{2}{*}{ Energy source } & \multicolumn{4}{|c|}{ Nitrogen source ${ }^{1}$} & \multirow[b]{2}{*}{ Mean } \\
\hline & Control & Casein & Soy peptone & Urea & \\
\hline \multicolumn{6}{|c|}{ Lactic acid bacteria $\left(\log _{10} \mathrm{CFU} / \mathrm{mL}\right)$} \\
\hline Starch & 7.544 & 7.902 & 8.382 & 7.003 & $7.708 \mathrm{~A}$ \\
\hline Mean & $6.542 \mathrm{bc}$ & $7.353 \mathrm{ab}$ & $7.958 \mathrm{a}$ & $6.152 \mathrm{c}$ & $\mathrm{CV}(\%)=8.6$ \\
\hline \multicolumn{6}{|c|}{$\mathrm{pH}$} \\
\hline Mean & $6.14 \mathrm{~b}$ & $6.16 \mathrm{~b}$ & $6.32 \mathrm{~b}$ & $6.72 \mathrm{a}$ & $\mathrm{CV}(\%)=3.5$ \\
\hline
\end{tabular}

${ }^{1}$ Means, in the same column followed by different capital letters, or in the same row followed by different lower case letters, are different $(\mathrm{P}<0.05)$ by Tukey test.

Table 3 - Concentration of lactic acid bacteria and $\mathrm{pH}$ of the culture after the fourth rumen inoculum transfer

\begin{tabular}{|c|c|c|c|c|c|}
\hline \multirow[b]{2}{*}{ Energy source } & \multicolumn{4}{|c|}{ Nitrogen source $^{1}$} & \multirow[b]{2}{*}{ Mean } \\
\hline & Control & Casein & Soy peptone & Urea & \\
\hline \multicolumn{6}{|c|}{ Lactic acid bacteria $\left(\log _{10} \mathrm{CFU} / \mathrm{mL}\right)$} \\
\hline Starch & 7.371 & 7.947 & 8.288 & 6.698 & $7.576 \mathrm{~A}$ \\
\hline Mean & $6.575 b$ & $7.250 \mathrm{ab}$ & $8.075 \mathrm{a}$ & $6.144 b$ & $\mathrm{CV}(\%)=12.3$ \\
\hline \multicolumn{6}{|c|}{$\mathrm{pH}$} \\
\hline Mean & $6.18 \mathrm{~b}$ & $6.16 \mathrm{~b}$ & $6.23 \mathrm{~b}$ & $6.71 \mathrm{a}$ & $\mathrm{CV}(\%)=3.7$ \\
\hline
\end{tabular}

${ }^{1}$ Means, in the same column followed by different capital letters, or in the same row followed by different lower case letters, are different $(\mathrm{P}<0.05)$ by Tukey test.

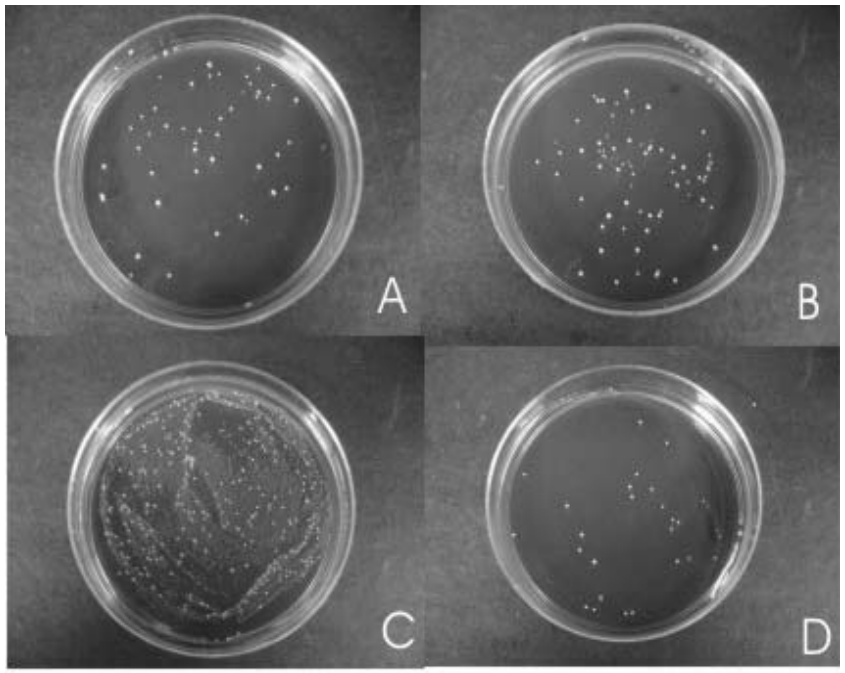

Figure 1 - Lactic acid bacteria growth on cellulose with different nitrogen sources after 24 hours (A - control; B - casein; C - soy peptone; and D - urea. The fluid was $100 \times$ diluted).

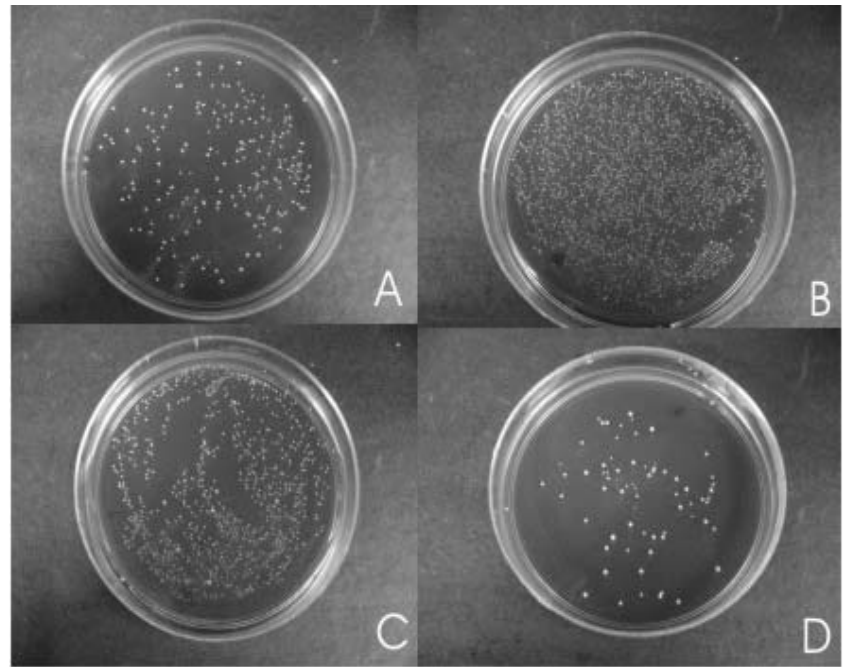

Figure 2 - Lactic acid bacteria growth in starch with different nitrogen sources after 24 hours (A - control; B - casein; C - soy peptone; and D - urea. The fluid was $10,000 \times$ diluted). 
Inhibition halos were not detected in the tests conducted with L. lactis and $R$. albus, when using LAB cultures or culture supernatant (Figures 1 and 2).

The rumen is composed of various microbial species, in which structural carbohydrate (SC) and non-structural carbohydrate (NSC) fermenting bacteria compete for resources such as ammonia, peptides and sulphur (Russell et al., 1992).

Because fibrous components are hydrolysed at slower rates compared to NSC, the energy obtained from fibre for microbial growth becomes available slowly. Therefore, the NSC fermenting bacteria grow at higher rates. However, fibrolytic microorganisms are physically associated with forage particles. This behaviour increases the competition with NSC fermenters, such as LAB, which are nonadherent. The inclusion of starch as a source of energy in incubations with rumen inoculum provided increased growth of $\mathrm{LAB}$, indicating that the supply of readily fermentable carbohydrates favours NSC fermenting bacteria at the expense of SC fermenters (Tables 2 and 3; Figures 1 and 2). This phenomenon, known as the "carbohydrate effect", increases competition for essential nutrients among groups of microbial species (El-Shazly et al., 1961; Mould et al., 1983). However, this effect does not favour the use of insoluble fiber by fibrolytic microorganisms (Rooke et al., 1987; Huhtanen, 1987; Paez-Bernal, 2007; Costa et al., 2009; Zorzi et al., 2009) leading to a lower growth rate and, consequently, to a lower capacity for competition.

Results obtained under tropical conditions indicate that the exclusive supplementation with true protein causes inhibition of the degradation of high quality forage fibre. This phenomenon is similar to the results of exclusive supplementation with sources of readily fermentable carbohydrates (Paez-Bernal, 2007; Costa et al., 2009; Zorzi et al., 2009).

In this study, it was demonstrated that protein supplementation (casein and soy peptone) leads to a higher LAB count, while the supplementation of non-protein nitrogen (urea) resulted in a $\mathrm{LAB}$ count equal to or lower than non-supplemented inoculum (Tables 2 and 3; Figures 1 and 2). This behaviour suggests that at least part of the deleterious effect on fibrolytic microbial growth observed with true protein supplementation is due to an increase in microbial competition.

Therefore, although fibrolytic bacteria possess adherent behaviour, which is a competitive advantage, the inclusion of starch and/or true protein sources stimulates the growth of bacteria that use rapidly fermentable carbohydrates (e.g., LAB), superseding the advantage of cellular adhesion to particles.

Lactic acid bacteria found in food such as cheese, have efficient protease activity, which can provide amino acids to the bacteria. As a result, these bacteria have the limited ability to bio-synthesise protein from ammonia (Hugenholtz \& Kleerebezem, 1999). Therefore, supplementation with non-protein nitrogenous compounds would not increase the availability of substrates for the growth of NSC fermenting bacteria. Thus, the ability to compete with SC fermenting bacteria can be effectively reduced. This corroborates the stimulus of the in vitro degradation of insoluble fibre from high-quality tropical forage observed by some authors when urea was used as nitrogen source (Paez-Bernal, 2007; Zorzi et al., 2009).

Some authors have reported the inhibition of fibrolytic enzyme activity due to the presence of starch in the medium. This seems to be associated with the release of inhibitory compounds (such as bacteriocins) by microorganisms that degrade starch (El-Shazly et al., 1961; Piwonka \& Firkins, 1993; Kalmokoff et al., 1996). In tropical conditions, it has been speculated that exclusive protein supplementation stimulates the production of bacteriocins (Paez-Bernal, 2007; Costa et al., 2009; Zorzi et al., 2009), which would be increased as increase availability of amino acids (De Vuyst \& Vandamme, 1993).

Lactic acid bacteria are responsible for the production of several types of bacteriocins (Axelsson, 2004). However, no antimicrobial activity was detected in the LAB isolated from the rumen in this study. Thus, under laboratory conditions, bacteriocins were not expressed or released, which indicates that competition dominates over the balance of activities of fibrolytic and non-fibrolytic microorganisms after supplementation with nitrogenous compounds.

However, further studies should be performed on the effect of bacteriocins on fibrolytic rumen activity because of the great difficulties in quantifying these inhibitory compounds.

The $\mathrm{pH}$ of the in vitro incubations with urea supplementation was higher than the control and protein supplemented incubations (Tables 2 and 3), which may have favoured SC fermenting bacteria.

Cellulolytic bacteria (e.g., Butyrivibrio fibrisolvens, Bacteroides succinogenes, Ruminoccocus albus and R. flavefasciens) demonstrate sensitivity to low $\mathrm{pH}$ (Russell \& Dombrowski, 1980). Mould et al. (1983) concluded that the growth of cellulolytic bacteria is completely inhibited at $\mathrm{pH}$ values below 6.0. In this study, the $\mathrm{pH}$ was maintained above 6.08 , however. 


\section{Conclusions}

Sources of true protein enhance non-structural carbohydrates fermenting bacteria growth, which can increase the competition with structural carbohydrates fermenting bacteria. These effects are not observed when nitrogen is provided as urea.

\section{References}

AASEN, I.M.; MØRETRØ, T.; KATLA, T. et al. Influence of complex nutrients, temperature and $\mathrm{pH}$ on bacteriocin production by Lactobacillus sakei CCUG 42687. Applied Microbiology and Biotechnology, v.53, p.159-166, 2000.

ATLAS, R.M. Media for environmental microbiology. 2.ed. Boca Raton: CRC Press, 2005. 454p.

AXELSSON, L. Classification and physiology. In: SALMINEN, S.; Von WRIGHT, A.; OUWEHAND, A.C. (Eds.) Lactic acid bacteria: microbiological and functional aspects. 3.ed. New York: Marcel Dekker, 2004. p.1-66.

CONE, J.W.; Van GELDER, A.H. Influence of protein fermentation on gas production profiles. Animal Feed Science and Technology, v.76, p.251-264, 1999.

COSTA, V.A.C. Desempenho nutricional de bovinos em pastejo durante o período das águas com suplementação protéica ou protéico-energética. 2009. 90f. Tese (Doutorado em Zootecnia) - Departamento de Zootecnia/Universidade Federal de Viçosa, Viçosa, MG.

COSTA, V.A.C.; DETMANN, E.; VALADARES FILHO, S.C. et al. Degradação in vitro da fibra em detergente neutro de forragem tropical de alta qualidade em função da suplementação com proteína e/ou carboidratos. Revista Brasileira de Zootecnia, v.38, p.1803-1811, 2009.

De MAN, J.C.; ROGOSA, M.; SHARPE, M.E. A medium for the cultivation of lactobacilli. Journal of Applied Bacteriology, v.23, p.130-135, 1960.

DETMANN, E.; PAUlino, M.F.; MANTOVANi, H.C. et al. Parameterization of ruminal fibre degradation in low-quality tropical forage using Michaelis-Menten kinetics. Livestock Science, v.126, p.136-146, 2009.

De VUYST, L.; VANDAMME, E.J.. Influence of the phosphorus and nitrogen source on nisin production in Lactococcus lactis subsp. lactis batch fermentations using a complex medium. Applied Microbiology and Biotechnology, v.40, p.17-22, 1993.

El-SHAZLY, K.; DEHORITY, B.A.; JONSON, R.R. Effect of starch on the digestion of cellulose in vitro and in vivo on rumen microorganisms. Journal of Animal Science, v.20, p.268-276, 1961.

HUGENHOLTZ, J.; KLEEREBEZEM, M. Metabolic engineering of lactic acid bacteria: overview of the approaches and results of pathway rerouting involved in food fermentations. Food Biotechnology, v.10, p.492-497, 1999.

HUHTANEN, P. The effects of intraruminal infusions of sucrose and xylose on the nitrogen and fibre digestion in the rumen of cattle receiving diets of grass silage and barley. Journal of Agriculture Science in Finland, v.59, p.101-120, 1987.

KALMOKOFF, M.L.; BARTLETT, F.; TEARHER, R.M. Are ruminal bacteria armed with bacteriocins? Journal of Animal Science, v.79, p.2297-2306, 1996.
KIM, W.S.; HALL, R.J.; DUNN, N.W. The effect of nisin concentration and nutrient depletion on nisin production of Lactococcus lactis. Applied Microbiology and Biotechnology, v.48, p.449-453, 1997.

MOULD, F.L.; ØRSKOV, E.R.; MANN, S.O. Associative effects of mixed feeds. I. Effects of type and level of supplementation and the influence of the rumen fluid $\mathrm{pH}$ on cellulolysis in vivo and dry matter digestion of various roughages. Animal Feed Science and Technology, v.10, p.15-30, 1983.

MOULD, F.L.; MORGAN, R.; KLIEM, K.E. et al. A review and simplification of the in vitro incubation medium. Animal Feed Science and Technology, v.123-124, p.155-172, 2005

OLIVEIRA, A.L.F.; CABRAL, L.S.; VALADARES FILHO, S.C. et al. Efeito da fermentação de proteínas na cinética de produção de gases in vitro. In: ZOOTEC'2005, Campo Grande. Anais... Campo Grande: Associação Brasileira de Zootecnistas, 2005 (CD-ROM)

PAEZ-BERNAL, D.M. Dinâmica de degradação in vitro da fibra em detergente neutro de capim-braquiária em função de suplementação com diferentes fontes de compostos nitrogenados e carboidratos. 2007. 49f. Dissertação (Mestrado em Zootecnia) - Universidade Federal de Viçosa, Viçosa, MG.

PARENTE, E.; RICCIARDI, A. Production, recovery and purification of bacteriocins from lactic acid bacteria. Applied Microbiology and Biotechnology, v.52, p.628-638, 1999.

PAULINO, M.F.; MORAES, E.H.B.K.; ZERVOUDAKIS, J.T. et al. Fontes de energia em suplementos múltiplos de auto-regulação de consumo na recria de novilhos mestiços em pastagem de capim Brachiaria decumbens durante o período das águas. Revista Brasileira de Zootecnia, v.34, p.957-962, 2005.

PAULINO, M.F.; DETMANN, E.; VALENTE, E.E.L. et al. Nutrição de bovinos em pastejo. In: SIMPÓSIO SOBRE MANEJO EStratéGiCo DA PAStagem, 4., 2008, Viçosa, MG. Anais... Viçosa, MG: DZO-UFV, 2008. p.131-169.

PIWONKA, E.J.; FIRKINS, J.L. Effect of glucose fermentation on fiber digestion by rumen microorganisms in vitro. Journal of Dairy Science, v.79, p.1196-2206, 1993.

PORTO, M.O. Suplementos múltiplos para recria e terminação de bovinos em pastejo durante o período das águas. 2005. 99f. Dissertação (Mestrado em Zootecnia) - DUniversidade Federal de Viçosa, Viçosa, MG.

ROOKE, J.A.; LEE, N.H.; ARMSTRONG, D.G. The effects of intraruminal infusions of urea, casein, glucose syrup and a mixture of glucose syrup and casein on nitrogen digestion in the rumen of cattle receiving grass silage diets. British Journal of Nutrition, v.57, p.89-98, 1987.

RUSSELL, J.B.; DOMBROWSKI, D.B. Effect of $\mathrm{pH}$ on the efficiency of growth by pure cultures of rumen bacteria in continuous culture. Applied and Environmental Microbiology, v.39, p.604-610, 1980.

RUSSELL, J.B.; O'CONNOR, J.D.; FOX, D.G. et al. A net carbohydrate and protein system for evaluating cattle diets: I. Ruminal fermentation. Journal of Animal Science, v.70, p.3551-3561, 1992.

TAGG, J.R.; DAJANI, A.S.; WANNAMAKER, L.W. Bacteriocins of gram-positive bacteria. Bacteriology Review, v.40, p.722-756, 1976.

WOLIN, M.J.; MILLER, T.L.; STEWART, C.S. Microbe-microbe interactions. In: HOBSON, P.N.; STEWART, C.S. (Eds.) The rumen microbial ecosystem. 2.ed. London: Chapman Hall, 1997. p.467-491.

ZORZI, K.; DETMANN, E.; QUEIROZ, A.C. et al. In vitro degradation of neutral detergent fiber of high-quality tropical forage according to supplementation with different nitrogenous compounds. Revista Brasileira de Zootecnia, v.38, p.964-971, 2009. 